\title{
SELECTED 5-AMINO-1-ARYL-1H-1,2,3-TRIAZOLE SCAFFOLDS AS PROMISING ANTIPROLIFERATIVE AGENTS
}

\author{
N. POKHODYLO ${ }^{1 \bowtie}$, O. SHYYKA ${ }^{1}$, N. FINIUK ${ }^{2}$, R. STOIKA ${ }^{2}$ \\ ${ }^{1}$ Ivan Franko National University of Lviv, Ukraine; \\ ${ }^{2}$ Institute of Cell Biology, National Academy of Sciences of Ukraine, Lviv; \\ e-mail: pokhodylo@gmail.com; stoika@cellbiol.lviv.ua
}

Received: 09 January 2020; Accepted: 25 June 2020

\begin{abstract}
Development of new effective drugs with low side effects and definite chemical characteristics needs identification of bioactive scaffolds for further structural optimization. New synthesized derivatives of 4-hetaryl-5-amino-1-aryl-1H-1,2,3-triazoles and 3H-[1,2,3]triazolo[4,5-b]pyridines were tested for anticancer activity using 60 human tumor cell lines within 9 cancer types. The selective influence of $(5$-amino- $1 \mathrm{H}$ 1,2,3-triazol-4-yl)quinazolin-4(3H)-ones: 2-(5-amino-1-(4-chlorophenyl)-1H-1,2,3-triazol-4-yl)quinazolin4(3H)-one and 2-(5-amino-1-phenyl-1H-1,2,3-triazol-4-yl)-6-bromoquinazolin-4(3H)-one on ovarian cancer OVCAR-4 cells with growth percentage $(G P)=-4.08$ and $6.63 \%$, respectively, was found. The derivative 5,7-diamino-3-(3-(trifluoromethyl)phenyl)-3H-[1,2,3]triazolo[4,5-b]pyridine-6-carbonitrile possessed high activity towards lung cancer EKVX cells $(G P=29.14 \%)$. The compounds were shown to be less toxic than doxorubicin towards non-tumor human embryonic kidney cells of HEK293 line. Thus, the results of our study confirm the anticancer potential of compounds based on 5-amino-1-aryl-1H-1,2,3-triazoles scaffolds and their fused polycyclic derivatives.
\end{abstract}

Keywords: 5-amino-1-aryl-1H-1,2,3-triazoles, 3H-[1,2,3]triazolo[4,5-b]pyridines, quinazolinones, thiazoles, 1,3,4-oxadiazoles, antiproliferative activity, anticancer activity.

$\mathrm{D}$ espite a huge number of existing anticancer chemotherapeuticals and efforts conducted in the academic and pharmaceutical investigations, the problem of effectiveness and selective cytotoxicity of drugs for drug-susceptible and drugresistant cancers remains unsolved. Thus, there is a continuous need to develop new effective drugs with low side effects and definite chemical characteristics leading to a systematic screening of new compounds and identification of bioactive scaffolds for further structural optimization.

5-Amino-1-aryl-1H-1,2,3-triazole motif was recognized as perspective for the development of novel drugs with high biodiversity and versatility, and they are studied in several ongoing clinical trials. For instance, the well-known drug carboxyamidotriazole (Fig. 1) capable of binding to and inhibiting of the non-voltage-operated $\mathrm{Ca}^{2+}$ channels and blocking cellular $\mathrm{Ca}^{2+}$ influx and release, cause a disruption of calcium channel-mediated signal transduction and inhibition of vascular endothelial growth factor signalling, endothelial proliferation, and angiogenesis [1]. This agent is also widely used in cancer therapy [2-4]. Carboxyamidotriazole inhibits growth of H345 small cell lung cancer cells via VEGF-dependent pathway. This compound was also effective in NCI-H209 cells proliferation in nude mice [5]. Carboxyamidotriazole was reported to inhibit growth of MCF-7 human breast cancer cells via apoptosis induction and cycle arrest in $\mathrm{G}(2) / \mathrm{M}$ phase [6]. The antineoplastic action of carboxyamidotriazole in combination with other drugs was studied. The combination of carboxyamidotriazole and glycolysis inhibitor 2-deoxyglucose inhibited the pancreatic cancer progression [3]. Chen et al. (2017) reported that the combination of sorafenib and carboxyamidotriazole inhibited the proliferation of nonsmall cell lung cancer cells of A549 and NCI-H1975 lines in vitro, and Lewis lung carcinoma bearing mice [4]. The application of carboxyamidotriazole

(C) 2020 Pokhodylo N. et al. This is an open-access article distributed under the terms of the Creative Commons Attribution License, which permits unrestricted use, distribution, and reproduction in any medium, provided the original author and source are credited. 
<smiles>NC(=O)c1nnn(Cc2cc(Cl)c(C(=O)c3ccc(Cl)cc3)c(Cl)c2)c1N</smiles>

Fig. 1. Carboxyamidotriazole

in the combination with $3^{\prime}, 4^{\prime}$-dimethoxyflavone or carboxyamidotriazole with 1-methyl-L-tryptophan resulted in higher anticancer activity than it was found for a single agent treatment [2].

In previous studies, we revealed two 5-amino-1H-1,2,3-triazole-4-carboxamides (5-amino-N(2,5-dichlorophenyl)-1-(4-methylphenyl)-1H-1,2,3triazole-4-carboxamide and 5-amino-N-(2,4dimethoxyphenyl)-1-(4-fluorophenyl)-1 $H$-1,2,3-triazole-4-carboxamide) that possessed the antiproliferative activity and were highly active towards renal cancer RXF 393 cells (GP $=-13.42 \%$ ) and the CNS cancer SNB-75 cells (GP = -27.30\%) respectively [7] (Fig. 2). Moreover, the amino-fused 1,2,3-triazole: 5-oxo-4,5,6,7,8,9-hexahydrobenzo[4,5]thieno[3,2-e] [1,2,3]triazolo[1,5-a]pyrimidine-3-carboxamide possessed a selective action towards melanoma SK-MEL-5 cells (GP $=-31,50 \%)$ [8] (Fig. 2). Other scaffolds such as 4-(1H-indole-3-carbonyl)-5-amino- $1 H$-1,2,3-triazoles, 4-arylsulfonyl-5-amine- $1 H$ 1,2,3-triazoles, [1,2,3]triazolo[1,5-a]quinazolines demonstrated moderate or low antiproliferative activity [7, 8] (Fig. 2). Recently, ethyl 5-amino-1-[4-(6oxo-4,5-dihydropyridazin-3-yl)phenyl]-1H-1,2,3triazole-4-carboxylate showed potent inhibitory activity against B-Raf kinase [9]. In addition to the anticancer studies, the 5-amino-1,2,3-triazole-4-carboxamide motif was found in compounds with the activity against Trypanosoma cruzi parasite [10] and compounds inhibiting LexA autoproteolysis and the bacterial SOS response [11].

Various 5-amino-1,2,3-triazoles were obtained by using an efficient synthetic method from the

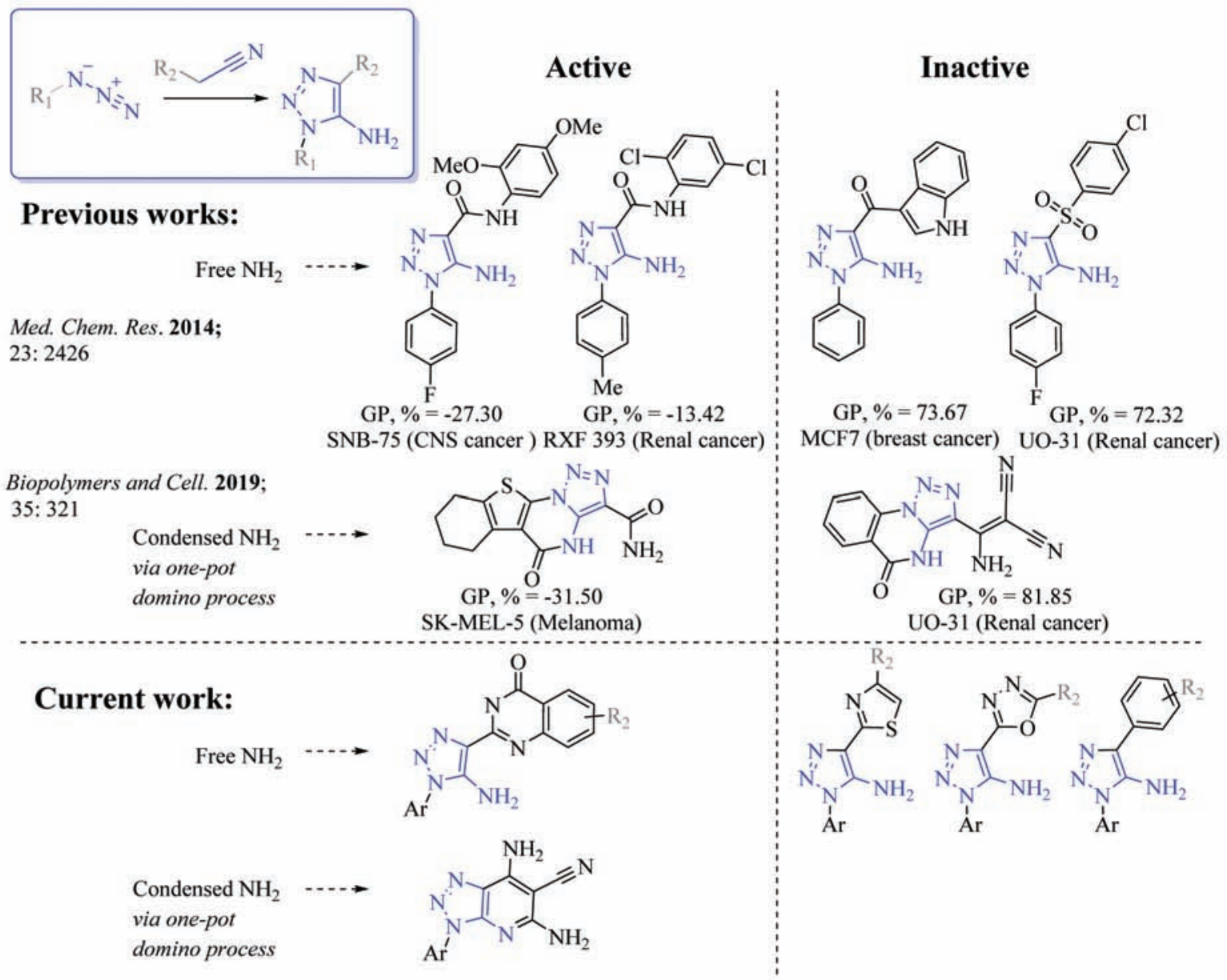

Fig. 2. The 5-amino-1H-1,2,3-triazole scaffolds under study 
available reagents via eco-friendly base-catalyzed cycloaddition reaction of azides with acetonitriles activated by aminodicyanovinyl fragment [12, 13], 1,3-thiazole [14, 15], 1,2,4-/1,3,4-oxadiazole [14], pyrroles and indoles [16] rings and with possible the simultaneous cascade processes leading to polycyclic systems [17, 18]. Additionally, the azide [3 + 2] cycloadditions can be performed at room temperature in good to excellent yields of products in the presence of catalytic amounts of pyrrolidine (5-10 mol\%) $[19,20]$ according to organocatalytic methodology [21-24]. Those protocols might be successfully used for the variation of the fragment in position 4 of the triazole, involving the electron-withdrawing heterocyclic core for an extended structure-activity investigation focused at drug-like properties. Moreover, the amino group formed in the reaction can be used for the annulation of the aromatic rings in a one-pot manner to synthesise the condensed polycyclic scaffolds via domino-process. That allows a rapid parallel synthesis and fast generation of the combinatorial libraries for screening of the biological activity $[25,26]$.

The present work was aimed on evaluation of the anticancer activity of new 5-amino-1-aryl- $1 \mathrm{H}$ 1,2,3-triazoles scaffolds and their fused derivatives synthesized at $20^{\circ} \mathrm{C}$ in a short time via azides cyclocondensation, as described $[12,14]$. The results of performed in vitro study of the anticancer activity of the synthesized compounds towards 60 cancer cell lines suggested the most promising lead candidates with selective influence suitable for further structural optimization. The utility of versatile azides and nitriles with substituents of different nature in the synthetic protocol for the 5-amino- $1 H$-1,2,3-triazole derivatives allowed evaluating the dependence between structure of the side chain and anticancer activity.

\section{Materials and Methods}

Studied compounds. The 5-amino-1-aryl-1H1,2,3-triazoles 3-6 and 3H-[1,2,3]triazolo[4,5- $b$ ] pyridines 7 derivatives were synthesized earlier at the Department of Organic Chemistry of Ivan Franko National University of Lviv, Ukraine $[12,14]$. Properties and spectral characteristics of compounds used in this study have been presented in $[12,14]$. The purity of compounds was established to be higher than $97 \%$, based on liquid chromatography-mass spectrometry examination. A $10 \mathrm{mM}$ stock solution of the testing samples were prepared by dissolving of compounds in dimethyl sulfoxide (DMSO, Sigma-Aldrich, St. Louis, Missouri, USA). Then, working solutions of these compounds were prepared using culture medium. Doxorubicin (Dox) was purchased from Actavis S.R.L. (Bucharest, Romania) and used as a positive control.

Cell cultures. Human lung adenocarcinoma A549 cells (non-small cell lung cancer cells), human cervical adenocarcinoma HeLa cells, human embryonic kidney HEK293 cells were obtained from Cell Collection of R.E. Kavetsky Institute of Experimental Pathology, Oncology and Radiobiology (Kyiv, Ukraine). Human ovarian carcinoma Skov3 cells were obtained from the American Type Culture Collection (ATCC, Manassas, VA, USA) and were donated by Dr. Sci. O. Stasyk (Institute of Cell Biology, National Academy of Sciences of Ukraine, Lviv, Ukraine). Cells were grown in the RPMI-1640 (PPA, Vienna, Austria) or DMEM (Sigma-Aldrich, St. Louis, Missouri, USA) medium supplemented with $10 \%$ of fetal bovine serum (Biowest, Nuaille, France). Cells were cultivated in the $\mathrm{CO}_{2}$-thermostate at $37^{\circ} \mathrm{C}$ in atmosphere of $95 \%$ air and $5 \% \mathrm{CO}_{2}$.

Anticancer assay using NCI protocol. Accordingly, to the protocol of the Drug Evaluation Branch at the National Cancer Institute in Bethesda (USA), a primary antiproliferative assay was performed within nine cancer types of approximately 60 human tumor cell lines panel. The tested compounds were added to the culture at a single concentration $\left(10^{-5} \mathrm{M}\right)$ and left for $48 \mathrm{~h}$ incubation. Sulforhodamine B (SRB) was used as protein binding dye for the end-point determinations. The percent of growth of the treated cells when compared to the untreated control cells was taken for each tested compound. The percentage of growth inhibition was evaluated spectrophotometrically versus controls (untreated cells). 100\% corresponds to growth seen in the untreated cells, while $0 \%$ indicates a lack of growth over the course of the assay (i.e. equal to the number of cells at time zero). $-100 \%$ results when all cells were killed.

Cell proliferation MTT assay. In vitro evaluation of the antiproliferative activity of the synthesized compounds and doxorubicin, used as a reference drug control, towards cancer cell lines was measured by using the 3-(4,5-dimethylthiazol2-yl)-2,5-diphenyl-tetrazolium bromide (MTT, Sigma-Aldrich, St. Louis, Mo, USA) test [27]. Tumor and pseudo-normal cells were seeded for $24 \mathrm{~h}$ in 96-well microtiter plates at a concentration of 
5,000 cells/well $(100 \mu 1 /$ well). Then cells were incubated for next $72 \mathrm{~h}$ with various additions of the synthesized compounds or doxorubicin $(0-100 \mu \mathrm{M})$. MTT that is converted to dark violet, water insoluble MTT formazan by the mitochondrial dehydrogenases, was used to determine viable cells according to the Sigma-Aldrich protocol. Absorbance Reader BioTek ELx800 (BioTek Instruments, Inc., Winooski, VT, USA) was used for reaction results measurement.

Statistical analysis. All data are presented as the mean (M) \pm standard deviation (SD), $n=4$. Results were analysed and illustrated with GraphPad Prism (version 6; GraphPad Software, San Diego, CA, USA). Statistical analyses were performed using two-way ANOVA with Dunnett multiple comparisons test. $P$-value of $<0.05$ was considered as statistically significant.

\section{Results and Discussion}

Convenient synthetic protocols for cycloaddition reactions of arylazides $\mathbf{1}$ with activated acetonitriles $\mathbf{2}$ allow rapid generation of compound libraries with structural diversity (Scheme). It is noteworthy that the reaction of aryl azides $\mathbf{1}$ with acetonitriles $\mathbf{2}$ in the presence of sodium methylate in methanol occurred at $20^{\circ} \mathrm{C}$ and fully satisfies "click"- and "green" chemistry requirements. However, heating of the reagents is required for the highest conversion of reactants in a reaction of aryl azides 1 with acetonitriles 2c-e leading to compounds 3, 6, 7. The list of the studied substituents, as well as the full structure of compounds 3-7 tested for in vitro anticancer activity, is presented in Table 1.
Evaluation of anticancer activity in vitro. The synthesized 5-amino-1-aryl-1H-1,2,3-triazoles 3-6 and $3 H$-[1,2,3]triazolo[4,5-b]pyridines 7 were submitted and evaluated at the single concentration of $10^{-5} \mathrm{M}$ towards a panel of the approximately 60 cancer cell lines. Human tumor cell lines were derived from nine different cancer types: leukemia, nonsmall cell lung, colon, CNS, melanoma, ovarian, renal, prostate and breast cancers. The primary anticancer assays were performed according to the NCI (USA) protocol (http://dtp.nci.nih.gov) described elsewhere [28-31]. The results for each compound are reported as the percentage of growth (GP) (Table 1). Range of growth (\%) shows the lowest and the highest growth found among different cancer cell lines. The most active compounds are shown in Table 1.

In comparison to previously studied 5 -amino1,2,3-triazole-4-carboxamide [7], the newly synthesized compounds 3-7 displayed slight or low activity at in vitro screening (selected results are shown in Table 1). The 5-amino-4-(4-oxo-3,4-dihydroquinazolin-2-yl)- $1 H$-1,2,3-triazoles 3 possess the inhibiting activity towards the ovarian cancer OVCAR-4 cell line. In particular, 1,2,3-triazoles 3a and $3 \mathbf{b}$ were found to be the most active among the quinazolines with growth inhibition $\mathrm{GP}=-4.08$ and $6.63 \%$, respectively.

On the contrary, the selective influence of $[1,2,3]$ triazolo[ $[4,5-b]$ pyridines $\mathbf{7 a - i}$ on single lung cancer cell line was observed, specifically the compound 7a was highly active on EKVX cell line $(\mathrm{GP}=29.14 \%)$. Unfortunately, compounds of another 3 scaffolds types 4,5 , and 6 were found to possess

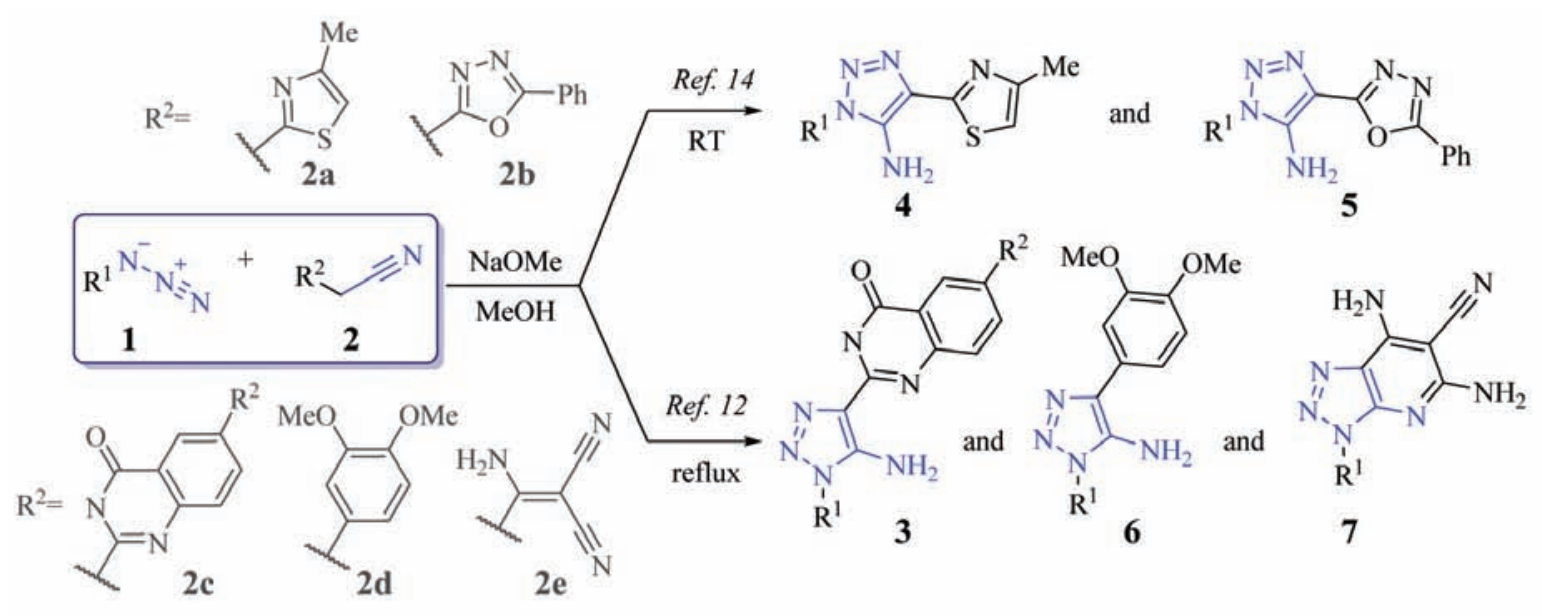

Scheme. Synthesis of 5-amino-1-aryl-1H-1,2,3-triazole scaffolds 
Table 1. Anticancer screening data at 10-5 M for selected 5-amino-1-aryl-1H-1,2,3-triazoles

\begin{tabular}{|c|c|c|c|c|c|}
\hline No & Compound & $\begin{array}{l}\text { Mean } \\
\text { GP\% }\end{array}$ & Range GP \% & The most sensitive cell lines & $\begin{array}{l}\text { Growth, } \\
\%\end{array}$ \\
\hline 3a & & 76.65 & -4.08 to 106.52 & $\begin{array}{l}\text { OVCAR-4 (Ovarian Cancer) } \\
\text { SNB-75 (CNS Cancer) } \\
\text { T-47D (Breast Cancer) 549/ } \\
\text { ATCC (Lung Cancer) }\end{array}$ & $\begin{array}{l}-4.08 \\
24.75 \\
27.21 \\
40.57\end{array}$ \\
\hline $3 \mathbf{b}$ & & 81.27 & 6.63 to 111.89 & $\begin{array}{l}\text { OVCAR-4 (Ovarian Cancer) } \\
\text { U251 (CNS Cancer) } \\
\text { NCI-H460 (Lung Cancer) } \\
\text { HCT-116 (Colorectal Cancer) }\end{array}$ & $\begin{array}{c}6.63 \\
38.57 \\
43.51 \\
48.22\end{array}$ \\
\hline 3c & & 97.08 & 68.84 to 119.80 & $\begin{array}{l}\text { SR (Leukemia) } \\
\text { NCI-H522 (Lung Cancer) } \\
\text { HCT-116 (Colorectal Cancer) }\end{array}$ & $\begin{array}{l}69.47 \\
68.84 \\
70.27\end{array}$ \\
\hline 4 & & 94.78 & 75.95 to 108.76 & $\begin{array}{l}\text { NCI-H522 (Lung Cancer) } \\
\text { T-47D (Breast Cancer) } \\
\text { A549/ATCC (Lung Cancer) } \\
\text { UACC-257 (Melanoma) }\end{array}$ & $\begin{array}{l}75.95 \\
76.44 \\
77.80 \\
79.56\end{array}$ \\
\hline 5 & & 96.04 & 74.39 to 109.30 & $\begin{array}{l}\text { A498 (Kidney Cancer) } \\
\text { NCI-H522 (Lung Cancer) } \\
\text { A549/ATCC (Lung Cancer) }\end{array}$ & $\begin{array}{l}74.39 \\
76.10 \\
79.77\end{array}$ \\
\hline 6 & & 100.47 & 65.45 to 116.00 & NCI-H522 (Lung Cancer) & 65.45 \\
\hline $7 \mathbf{a}$ & & 87.34 & 29.14 to 120.64 & $\begin{array}{l}\text { EKVX (Lung Cancer) } \\
\text { HS 578T (Breast Cancer) } \\
\text { T-47D (Breast Cancer) } \\
\text { MCF7 (Breast Cancer) }\end{array}$ & $\begin{array}{l}29.14 \\
46.17 \\
48.07 \\
60.15\end{array}$ \\
\hline $7 \mathbf{b}$ & & 90.52 & 45.26 to 110.76 & $\begin{array}{l}\text { EKVX (Lung Cancer) } \\
\text { HS 578T (Breast Cancer) } \\
\text { A549/ATCC (Lung Cancer) } \\
\text { NCI-H522 (Lung Cancer) }\end{array}$ & $\begin{array}{l}31.52 \\
45.26 \\
77.20 \\
65.56\end{array}$ \\
\hline 7c & & 91.48 & 38.20 to 122.37 & $\begin{array}{l}\text { EKVX (Lung Cancer) } \\
\text { NCI-H522 (Lung Cancer) }\end{array}$ & $\begin{array}{l}\mathbf{3 8 . 2 0} \\
72.33\end{array}$ \\
\hline 7d & & 98.96 & 39.08 to 122.40 & $\begin{array}{l}\text { EKVX (Lung Cancer) } \\
\text { HS 578T (Breast Cancer) }\end{array}$ & $\begin{array}{l}39.08 \\
75.96\end{array}$ \\
\hline $7 e$ & & 97.49 & 43.45 to 118.96 & $\begin{array}{l}\text { EKVX (Lung Cancer) } \\
\text { T-47D (Breast Cancer) }\end{array}$ & $\begin{array}{l}43.45 \\
73.57\end{array}$ \\
\hline
\end{tabular}


Table 1. (Continuation)

\begin{tabular}{|c|c|c|c|c|c|}
\hline No & Compound & $\begin{array}{l}\text { Mean } \\
\text { GP\% }\end{array}$ & Range GP \% & The most sensitive cell lines & $\begin{array}{c}\text { Growth, } \\
\%\end{array}$ \\
\hline $7 f$ & & 96.08 & 43.61 to 119.29 & $\begin{array}{l}\text { EKVX (Lung Cancer) } \\
\text { T-47D (Breast Cancer) } \\
\text { HS 578T (Breast Cancer) } \\
\text { MCF7 (Breast Cancer) }\end{array}$ & $\begin{array}{l}43.61 \\
67.15 \\
68.79 \\
71.42\end{array}$ \\
\hline $7 g$ & & 95.58 & 44.78 to 122.77 & $\begin{array}{l}\text { EKVX (Lung Cancer) } \\
\text { HS 578T (Breast Cancer) } \\
\text { NCI-H522 (Lung Cancer) } \\
\text { A549/ATCC (Lung Cancer) }\end{array}$ & $\begin{array}{l}44.78 \\
61.63 \\
69.36 \\
81.56\end{array}$ \\
\hline $7 \mathrm{~h}$ & & 98.00 & 50.24 to 119.60 & $\begin{array}{l}\text { EKVX (Lung Cancer) } \\
\text { NCI-H522 (Lung Cancer) } \\
\text { A549/ATCC (Lung Cancer) }\end{array}$ & $\begin{array}{l}50.24 \\
77.24 \\
84.51\end{array}$ \\
\hline $7 \mathbf{i}$ & $n_{2}$ & 93.43 & 63.00 to 115.30 & $\begin{array}{l}\text { EKVX (Lung Cancer) } \\
\text { NCI-H522 (Lung Cancer) } \\
\text { UO-31 (Kidney Cancer) }\end{array}$ & $\begin{array}{l}63.00 \\
65.83 \\
70.22\end{array}$ \\
\hline
\end{tabular}

activity below moderate (mostly active on NCIH522 Lung Cancer cell line) (Table 1). In general, it can be concluded that the replacement of the amide moiety at position 4 of $1 H-1,2,3$-triazole leads to a decrease or loss of its anticancer activity. Nevertheless, triazoles $\mathbf{3}$ and $\mathbf{7}$ studied in current work, with the partially preserved amide moiety remained active. Meanwhile, the introduction of other bioisosters such as thiazole and oxadiazole, led to a decrease in activity, and moreover, the replacement with sulfo- or aryl substituent generally led to activity disappearance (Fig. 3). The introduction of the donor substituent in the aryl moiety at position 1 , and any limitation of rotation of this moiety due to the substituent in the ortho position to triazole also assist the activity decrease. Such data suggest a possibility of the same mechanism of action of the studied scaffolds in comparison to known carboxyamidotriazole (Fig. 1).

The antiproliferative activity of three 5 -amino-1-aryl-1H-1,2,3-triazoles (3a, 3b, and 7a) were evaluated in human carcinoma cell lines of different tissue origin: ovarian (Skov3), cervical (HeLa), lung (A549) and towards human embryonic kidney HEK293 cells using the MTT test. It was found that compound 3a possessed the highest cytotoxic
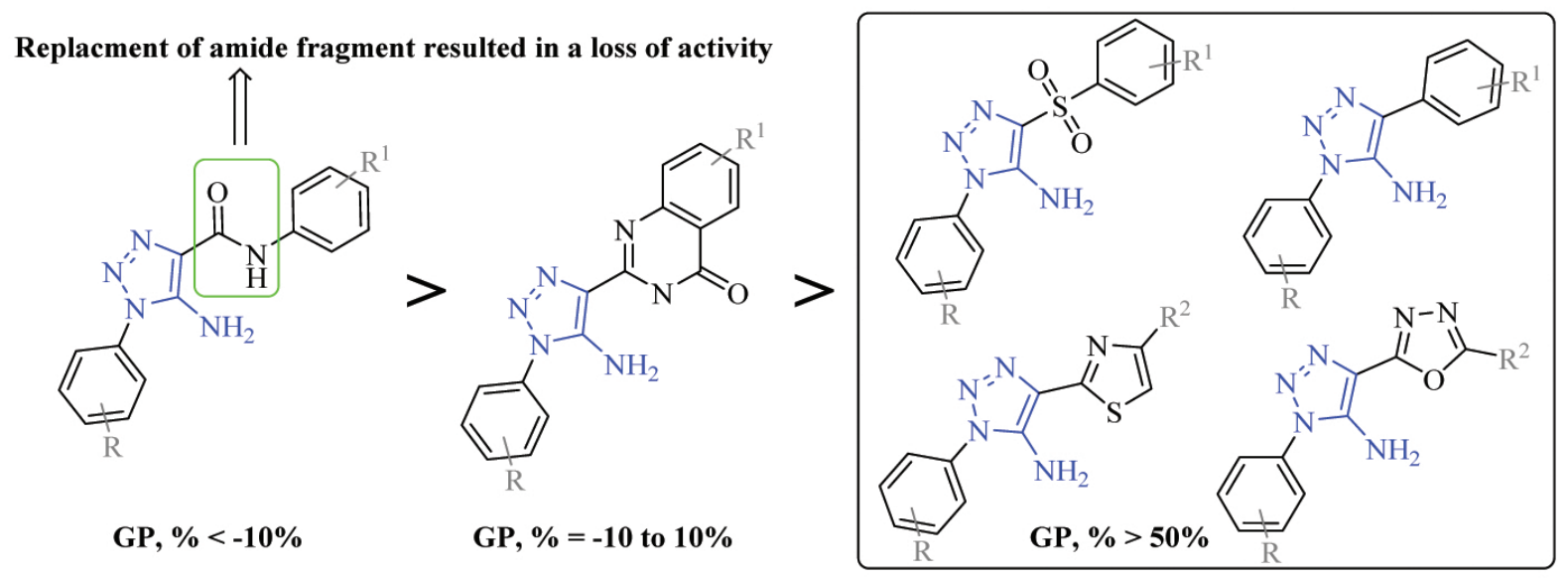

Fig. 3. Structure-activity dependence 

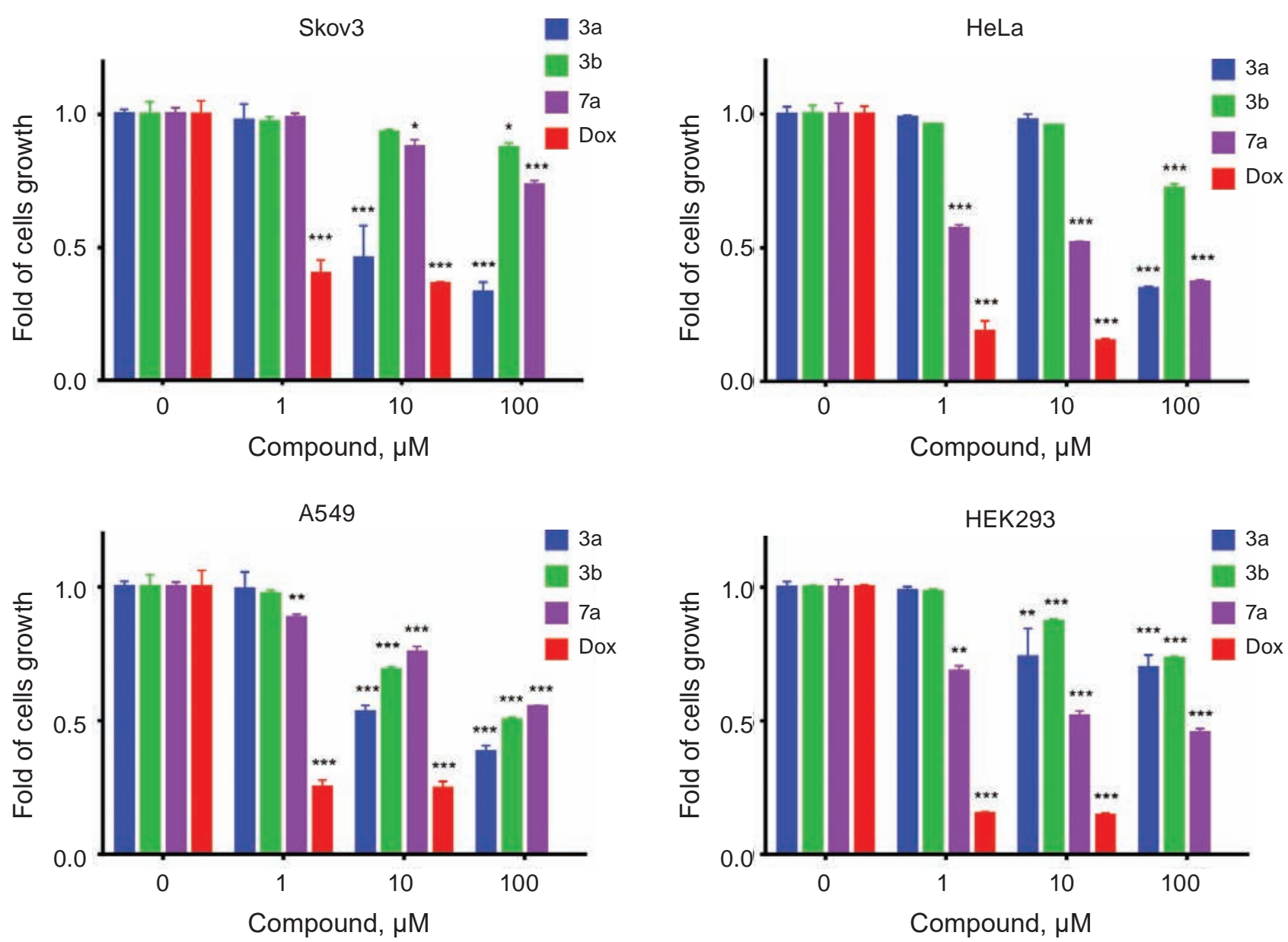

Fig. 4. Level of cytotoxicity of three 5-amino-1-aryl-1H-1,2,3-triazoles (3a, 3b, and 7a) towards human carcinoma cell lines of different tissue origin: ovarian (Skov3), cervical (HeLa), lung (A549), and towards nontumor cells (HEK293). After a total experimental time (72 h), cell vitality was detected by the MTT assay. ${ }^{*} P \leq 0.05 ;{ }^{* * P} \leq 0.01 ; * * * P \leq 0.001$ (difference compared with the no treated control cells). Dox-doxorubicin

action towards studied tumor cells. Compound 3a inhibited growth of human ovarian carcinoma Skov3 cells with the $\mathrm{IC}_{50}$ of $9.1 \mu \mathrm{M}$ (Fig. 4, Table 2). The $\mathrm{IC}_{50}$ value for compound 3a was $78.1 \mu \mathrm{M}$ in human cervical adenocarcinoma HeLa cells, and $28.7 \mu \mathrm{M}-$ in human lung adenocarcinoma A549 cells (Fig. 4, Table 2). The $\mathrm{IC}_{50}$ value for A549 cells was $99.6 \mu \mathrm{M}$ for compound $\mathbf{3 b}$ (Fig. 4, Table 2). At the highest dose of $100 \mu \mathrm{M}$, compound $\mathbf{3 b}$ inhibited the growth of Skov3 cells by $12.6 \%$, and the growth of HeLa cells - by $27.8 \%$ (Fig. 4, Table 2). Compound 7a inhibited growth of HeLa cells with the $\mathrm{IC}_{50}$ of $20.4 \mu \mathrm{M}$ (Fig. 4, Table 2). Compound 7a inhibited Skov3 and A549 cells growth by 26.5 and $44.8 \%$, respectively (Fig. 4, Table 2). Doxorubicin demonstrated higher cytotoxicity towards Skov3, HeLa and $\mathrm{A} 549$ tumor cells $\left(\mathrm{IC}_{50}\right.$ was $0.8 \mu \mathrm{M}, 0.6 \mu \mathrm{M}$, and $0.6 \mu \mathrm{M}$, respectively, Fig. 4, Table 2).
We have also studied the toxicity of three 5-amino-1-aryl-1H-1,2,3-triazoles (3a, 3b, and 7a) towards human embryonic kidney HEK293 cells. HEK293 cells were relatively non-sensitive to the action of compounds $\mathbf{3 a}$, $\mathbf{3 b}$ and $\mathbf{7 a}$. The $\mathrm{IC}_{50}$ level was above $100 \mu \mathrm{M}$ under compounds $\mathbf{3 a}$ and $\mathbf{3 b}$ treatment, while $\mathrm{IC}_{50}$ for compound 7a was $38.6 \mu \mathrm{M}$ (Fig. 4, Table 2). The $\mathrm{IC}_{50}$ value of doxorubicin was $0.5 \mu \mathrm{M}$ that indicates high cytotoxic effect of the chemotherapeutic drug towards HEK293 cells (Fig. 4, Table 2).

Conclusion. Anticancer activity in vitro for the selected 5-amino-1-aryl-1H-1,2,3-triazoles and their fused polycyclic derivatives $3 H$-[1,2,3]triazolo[4,5b]pyridines was evaluated. New 5-amino-1-aryl- $1 H$ 1,2,3-triazole scaffold (5-amino-1H-1,2,3-triazol4-yl)quinazolin-4(3H)-one) was found to possess the antitumor activity with a selective influence on 
Table 2. Cytotoxicity indicator $\left({ }^{2} C_{50}\right)$ of three 5-amino-1-aryl-1H-1,2,3-triazoles $(3 a, 3 b$, and $7 a)$ and doxorubicin (Dox) towards human carcinoma cell lines of different tissue origin: ovarian (Skov3), cervical (HeLa), lung (A549) and towards pseudo-normal HEK293 cells

\begin{tabular}{l|c|c|c|c}
\hline \multirow{2}{*}{ Cell line } & \multicolumn{4}{c}{$\mathrm{IC}_{50}, \mu \mathrm{M}$} \\
\cline { 2 - 5 } & 3a & 3b & $\mathbf{7 a}$ & Dox \\
\hline Human ovarian carcinoma Skov3 cells & 9.1 & $>100$ & $>100$ & 0.8 \\
Human cervical adenocarcinoma HeLa cells & 78.1 & $>100$ & 20.4 & 0.6 \\
Human lung adenocarcinoma A549 cells & 28.7 & 99.6 & $>100$ & 0.6 \\
Human embryonic kidney HEK293 cells & $>100$ & $>100$ & 38.6 & 0.5 \\
\hline
\end{tabular}

single cell line OVCAR-4 (ovarian cancer). Taking into account these results, further structure optimization to design more selective and active anticancer agents among 5-amino-1-aryl-1H-1,2,3-triazoles is in progress.

The obtained results allowed identifying the most active (5-amino-1H-1,2,3-triazol-4-yl)quinazolin-4(3H)-ones: 2-(5-amino-1-(4-chlorophenyl)- $1 H$ 1,2,3-triazol-4-yl)quinazolin-4(3H)-one and 2-(5-amino-1-phenyl-1H-1,2,3-triazol-4-yl)-6-bromoquinazolin-4(3H)-one towards ovarian cancer OVCAR-4 cells with GP $=-4.08$ and GP $=6.63 \%$, respectively. The 5,7-diamino-3-(3-(trifluoromethyl) phenyl)-3H-[1,2,3]triazolo[4,5- $b]$ pyridine-6-carbonitrile possessed a significant cytotoxic activity towards lung cancer EKVX cells (GP $=29.14 \%)$. The most prominent cytotoxic effect was demonstrated by the 2-(5-amino-1-(4-chlorophenyl)-1H-1,2,3-triazol-4-yl)quinazolin-4(3H)-one compound towards human ovarian carcinoma Skov3 cells. 2-(5-amino1-phenyl-1H-1,2,3-triazol-4-yl)-6-bromoquinazolin4(3H)-one and 5,7-diamino-3-(3-(trifluoromethyl) phenyl)-3H-[1,2,3]triazolo[4,5-b]pyridine-6-carbonitrile compounds possessed a remarkable cytotoxic activity towards cervical and lung carcinoma cell lines, however, their toxicity was less compared with the doxorubicin's one. These compounds were also less toxic than doxorubicin towards human embryonic kidney HEK293 cells. A search for more selective and active anticancer agents among 5-amino- $1 H-1,2,3-$ triazoles is conducted.

Conflict of interest. Authors have completed the Unified Conflicts of Interest form at http://ukrbiochemjournal.org/wp-content/uploads/2018/12/ coi_disclosure.pdf and declare no conflict of interest.
Acknowledgments. The authors are grateful to Dr. V. L. Narayanan (Drug Synthesis and Chemistry Branch, National Cancer Institute, Bethesda, MD, USA) for in vitro evaluation of the anticancer activity. The authors also thank Dr. Oleh Stasyk (Institute of Cell Biology, National Academy of Sciences of Ukraine, Lviv, Ukraine) for donating human ovarian carcinoma cells of Skov3 line.

Funding. The Ministry of Education and Science of Ukraine (Grant No 0118U003610) and National Research Foundation of Ukraine (project "New azole and cage-like agents against cancer and pathogenic microorganisms") are acknowledged for the financial support of this work.

\section{ПЕРСПЕКТИВНІ \\ АНТИПРОЛІФЕРАТИВНІ АГЕНТИ НА ОСНОВІ 5-АМІНО-1-АРИЛ-1H- 1,2,3-ТРИАЗОЛІВ}

Н. Т. Походило ${ }^{1 \bowtie}$, О. Я. Шийка ${ }^{1}$, Н. С. Фінюк ${ }^{2}$, Р. С. Стойка ${ }^{2}$

${ }^{1}$ Львівський національний університет імені Івана Франка, Україна;

${ }^{2}$ Інститут біології клітини НАН України, Львів; 『e-mail: pokhodylo@gmail.com; stoika@cellbiol.lviv.ua

Розробка нових ефективних лікарських препаратів 3 послабленою побічною дією та визначеними хімічними властивостями потребує систематичного скринінгу нових сполук та визначення біоактивного скафолду для подальшої структурної оптимізації. Синтезовані нові похідні 4-гетарил-5-аміно-1-арил-1 $H$-1,2,3триазолів та $3 H-[1,2,3]$ триазоло[4,5-b]піридинів протестовано на протиракову активність 
на 60 клітинних лініях NCI60 в межах 9 типів раку. Виявлено селективний вплив (5-аміно$1 H-1,2,3$-триазол-4-іл)хіназолін-4(3H)-онів: 2-(5-аміно-1-(4-хлорофеніл)-1H-1,2,3-триазол-4іл)хіназолін-4(3H)-ону і 2-(5-аміно-1-феніл- $H$ 1,2,3-триазол-4-іл)-6-бромхіназолін-4(3H)-ону на клітини OVCAR-4 раку яєчника $3 \mathrm{GP}=-4,08$ та 6,63\% відповідно. Виявлено, що 5,7-діаміно-3-(3(трифторметил)феніл)-3H-[1,2,3]триазоло[4,5-b] піридин-6-карбонітрил мав значну активність щодо клітин EKVX раку легенів (GP = 29,14\%). Встановлено, що сполуки були менш токсичними, ніж доксорубіцин щодо непухлинних клітин HЕК293 нирки ембріона людини. Такі результати $є$ важливими для отримання більш селективних і активних протипухлинних засобів на основі 5-аміно-1-арил-1H-1,2,3-триазолів та їх конденсованих поліциклічних похідних.

К л юч ов і слов а: 5-аміно-1-арил- $1 H$ 1,2,3-триазоли, $3 H$-[1,2,3]триазоло[4,5-b]піридини, хіназолінони, тіазоли, 1,3,4-оксадіазоли, антипроліферативна активність, протипухлинна активність.

\section{References}

1. Soltis MJ, Yeh HJ, Cole KA, Whittaker N, Wersto RP, Kohn EC. Identification and characterization of human metabolites of CAI [5-amino-11(4'-chlorobenzoyl-3,5-dichlorobenzyl)-1,2,3triazole- 4-carboxamide). Drug Metab Dispos. 1996; 24(7): 799-806.

2. Shi J, Chen C, Ju R, Wang Q, Li J, Guo, Ye C, Zhang D. Carboxyamidotriazole combined with IDO1-Kyn-AhR pathway inhibitors profoundly enhances cancer immunotherapy. J Immunother Cancer. 2019; 7(1): 246.

3. Ju R, Fei K, Li S, Chen C, Zhu L, Li J, Zhang D, Guo L, Ye C. Metabolic mechanisms and a rational combinational application of carboxyamidotriazole in fighting pancreatic cancer progression after chemotherapy. Pharmacol Exp Ther. 2018; 367(1): 20-27.

4. Chen C, Ju R, Shi J, Chen W, Sun F, Zhu L, Li J, Zhang D, Ye C, Guo L. Carboxyamidotriazole synergizes with sorafenib to combat non-small cell lung cancer through inhibition of NANOG and aggravation of apoptosis. J Pharmacol Exp Ther. 2017; 362(2): 219-229.

5. Moody TW, Chiles J, Moody E, Sieczkiewicz GJ, Kohn EC. CAI inhibits the growth of small cell lung cancer cells. Lung Cancer. 2003; 39(3): 279-288.

6. Guo L, Li ZS, Wang HL, Ye CY, Zhang DC. Carboxyamido-triazole inhibits proliferation of human breast cancer cells via G(2)/M cell cycle arrest and apoptosis. Eur J Pharmacol. 2006; 538(1-3): 15-22.

7. Pokhodylo NT, Shyyka OYa, Matiychuk VS. Synthesis and anticancer activity evaluation of new 1,2,3-triazole-4-carboxamide derivatives. Med Chem Res. 2014; 23(5): 2426-2438.

8. Shyyka OYa, Pokhodylo NT, Finiuk NS. Anticancer activity evaluation of thieno[3,2-e] $[1,2,3]$ triazolo[1,5-a]pyrimidines and thieno[2,3-e][1,2,3]triazolo[1,5-a]pyrimidine derivatives. Biopolym Cell. 2019; 35(4): 321-330.

9. ThabitMG, MostafaAS, SelimKB, Elsayed MAA, Nasr MNA. Design, synthesis and molecular modeling of phenyl dihydropyridazinone derivatives as B-Raf inhibitors with anticancer activity. Bioorg Chem. 2020; 103: 104148.

10. Brand S, Ko EJ, Viayna E, Thompson S, Spinks D, Thomas M, Sandberg L, Francisco AF, Jayawardhana S, Smith VC, Jansen C, De Rycker M, Thomas J, MacLean L, Osuna-Cabello M, Riley J, Scullion P, Stojanovski L, Simeons FRC, Epemolu O, Shishikura Y, Crouch SD, Bakshi TS, Nixon CJ, Reid IH, Hill AP, Underwood TZ, Hindley SJ, Robinson SA, Kelly JM, Fiandor JM, Wyatt PG, Marco M, Miles TJ, Read KD, Gilbert IH. Discovery and Optimization of 5-Amino1,2,3-triazole-4-carboxamide Series against Trypanosoma cruzi. J Med Chem. 2017; 60(17): 7284-7299.

11. Mo CY, Culyba MJ, Selwood T, Kubiak JM, Hostetler ZM, Jurewicz AJ, Keller PM, Pope AJ, Quinn A, Schneck J, Widdowson KL, Kohli RM. Inhibitors of LexA Autoproteolysis and the Bacterial SOS Response Discovered by an Academic-Industry Partnership. ACS Infect Dis. 2018; 4(3): 349-359.

12. Pokhodylo NT, Shyyka OYa. New cascade reaction of azides with malononitrile dimer to polyfunctional[1,2,3]triazolo[4,5-b]pyridine. Synth Comm. 2017; 47(11): 1096-1101.

13. Pokhodylo NT, Shyyka OYa, Tupychak MA, Obushak MD. Selectivity in domino-reaction of ortho-carbonyl azides with malononitrile dimer leading to [1,2,3]triazolo[1,5-a]pyrimidines. Chem Heterocycl Compd. 2018; 54(2): 209-212. 
14. Pokhodylo NT, Matiychuk VS. Synthesis of new 1,2,3-triazolo[1,5-a]quinazolinones. $J$ Heterocycl Chem. 2010; 47(2): 415-420.

15. Pokhodylo NT, Matiychuk VS, Obushak MD. Synthesis of the $1 \mathrm{H}-1,2,3$-triazole derivatives by the cyclization of arylazides with 1-(1,3-benzothiazol-2-yl)acetone, 1,3-benzothiazol-2ylacetonitrile and (4-aryl-1,3-thiazol-2-yl) acetonitrile. Chem Heterocycl Compd. 2009; 45(4): 483-488.

16. Pokhodylo NT, Matiychuk VS, Obushak MD. synthesis of triazoles via regioselective reactions of aryl azides with cyanoacetyl pyrroles and indoles. Synthesis. 2009; (8): 1297-1300.

17. Pokhodylo NT, Shyyka OYa, Obushak MD. Facile and efficient one-pot procedure for thieno[2,3-e] [1,2,3]triazolo[1,5-a]pyrimidines preparation. Synth Commun. 2014; 44(7): 1002-1006.

18. Pokhodylo NT, Shyyka OYa, Savka RD, Obushak MD. Novel Selected Tandem Transformations of the Amino and Carbonyl/ Nitrile Groups in the Gewald Thiophenes. Phosphorus Sulfur Silicon Relat Elem. 2010; 185(10): 2092-2100.

19. Saraiva MT, Costa GP, Seus N, Schumacher RF, Perin G, Paixão MW, Luque R, Alves D. Roomtemperature organocatalytic cycloaddition of azides with $\beta$-keto sulfones: toward sulfonyl1,2,3-triazoles. Org Lett. 2015; 17(24): 62066209.

20. Blastik ZE, Klepetarova B, Beier P. EnamineMediated Azide-Ketone [3+2] Cycloaddition of Azidoperfluoroalkanes. ChemistrySelect. 2018; 3(25): 7045-7048.

21. Ramachary DB, Ramakumar K, Narayana VV. Amino acid-catalyzed cascade [3+2]-cycloaddition/hydrolysis reactions based on the push-pull dienamine platform: synthesis of highly functionalized NH-1,2,3-triazoles. Chem Eur J. 2008; 14(30): 9143-9147.

22. Belkheira M, Abed DE, Pons JM, Bressy C. Organocatalytic synthesis of 1,2,3-triazoles from unactivated ketones and arylazides. Chem Eur J. 2011; 17(46): 12917-12921.
23. Organocatalytic enamide-azide cycloaddition reactions: regiospecific synthesis of 1,4,5-trisubstituted-1,2,3-triazoles. Chemistry. 2011; 17(13): 3584-3587.

24. Li W, Du Z, Huang J, Jia Q, Zhang K, Wang J. Direct access to 1,2,3-triazoles through organocatalytic 1,3-dipolar cycloaddition reaction of allyl ketones with azides. Green Chem. 2014; 16(6): 3003-3006.

25. Alba AN, Companyo X, Viciano M, Rios R. Organocatalytic Domino Reactions. Curr Org Chem. 2009; 13(14): 1432-1474.

26. Eschenbrenner-Lux V, Waldmann H, Kumar K. Chapter 13. Domino Reactions in Library Synthesis. In Domino Reactions: Concepts for Efficient Organic Synthesis, L.F. Tietze (Ed.). Wiley-VCH Verlag GmbH \& Co. KgaA, 2014: 497-522.

27. Liu X, Zu Y, Fu Y, Yao L, Gu C, Wang W, Efferth T. Antimicrobial activity and cytotoxicity towards cancer cells of Melaleuca alternifolia (tea tree) oil. Eur Food Res Technol. 2009; 229(2): 247253.

28. Monks A, Scudiero D, Skehan P, Shoemaker R, Paull K, Vistica D, Hose C, Langley J, Cronise P, Vaigro-Wolff A, Gray-Goodrich M, Campbell H, Mayo J, Boyd M. Feasibility of a high-flux anticancer drug screen using a diverse panel of cultured human tumor cell lines. J Natl Cancer Inst. 1991; 83(11): 757-766.

29. Boyd MR, Paull KD. Some practical considerations and applications of the National Cancer Institute in vitro anticancer drug discovery screen. Drug Dev Res. 1995; 34(2): 91-109.

30. Boyd MR. The NCI In Vitro Anticancer Drug Discovery Screen. In: Teicher B.A. (eds) Anticancer Drug Development Guide. Cancer Drug Discovery and Development. Totowa, NJ: Humana Press, 1997: 23-43.

31. Shoemaker RH. The NCI60 human tumour cell line anticancer drug screen. Nat Rev Cancer. 2006; 6(10): 813-823. 